\title{
Very low levels of waterborne butyltins modulate hemocyte function in the blue mussel Mytilus edulis
}

\author{
S. D. St-Jean ${ }^{1,2}$, É. Pelletier ${ }^{2, *}$, S. C. Courtenay ${ }^{1}$ \\ ${ }^{1}$ Fisheries and Oceans Canada, Gulf Fisheries Centre, PO Box 5030, Moncton, New Brunswick E1C 9B6, Canada \\ ${ }^{2}$ Institut des sciences de la mer de Rimouski (ISMER), Université du Québec à Rimouski, 310 Allée des Ursulines, Rimouski, \\ Québec G5L 3A1, Canada
}

\begin{abstract}
Hemocyte functions were used to determine the effect of very low concentrations $(1,3$ and $6 \mathrm{ng} \mathrm{Sn} \mathrm{l}^{-1}$ ) of tributyltin (TBT) and dibutyltin (DBT) on the internal defense of adult blue mussel Mytilus edulis under flow-through conditions over $11 \mathrm{~d}$. Hemolymph was sampled without harming mussels on Days 0, 1, 4 and 11 for measures of hemocyte count (HC), lysosome retention (LR) and phagocytic activity (PA). HC was increased from Day 1 by TBT at $6 \mathrm{ng} \mathrm{l}^{-1}$ and by DBT at 3 and $6 \mathrm{ng}$ $\mathrm{l}^{-1}$ on Day 11. LR was increased by both butyltins at concentrations as low as $1 \mathrm{ng} \mathrm{l}^{-1}$ from Day 4. PA was increased by DBT at $6 \mathrm{ng} \mathrm{l}^{-1}$ from Day 4. No difference was detected between the impacts of TBT and DBT on LR but TBT had a greater impact on HC and DBT had a greater impact on PA. These results support the hypothesis that both TBT and DBT can cause modulations of the internal defense

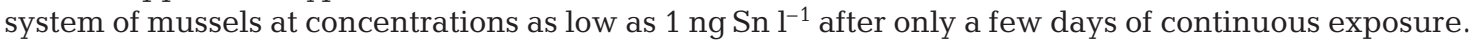

KEY WORDS: Immunotoxicity $\cdot$ Butyltins $\cdot$ TBT $\cdot$ DBT $\cdot$ Mussels $\cdot$ Hemocyte $\cdot$ Functions $\cdot$ Low level exposure $\cdot$ LOEL

Resale or republication not permitted without written consent of the publisher

\section{INTRODUCTION}

The use of organotins in the synthesis of a wide range of industrial products and in various biocides has resulted in variable concentrations of these highly toxic substances (Fent 1996) in water and sediments of all continents, except Antarctica (de Mora 1996). Organotins are hydrophobic molecules with relatively high solid/liquid partition coefficients (log Kps $\approx 3$ to 4) which tend to adsorb onto suspended particulate matter and concentrate in recent sediment layers. In spite of a number of studies having reported high concentrations of tributyltin (TBT) and dibutyltin (DBT) in sediments of harbors, marinas and navigation channels (Higashiyama et al. 1991, Fent 1996, St-Jean et al. 1999), their concentrations in the water column are highly variable ranging from $<0.1 \mathrm{ng} \mathrm{Sn}^{-1}$ in the open ocean (Hashimoto et al. 1998) up to $382 \mathrm{ng}$ TBT

${ }^{*}$ Corresponding author. E-mail: emilien_pelletier@uqar.qc.ca $\mathrm{l}^{-1}$ in some Danish harbors (Kure \& Depledge 1994). Michel \& Averty (1999) conducted an exhaustive monitoring of butyltins in French coastal waters and observed that $75 \%$ of their measurements exceeded the detection limit of $1 \mathrm{ng} \mathrm{TBT} l^{-1}\left(\approx 0.4 \mathrm{ng} \mathrm{Sn}^{-1}\right)$ and the overall average for all sampled sites was $4.6 \mathrm{ng}$ TBT $\mathbf{l}^{-1}$.

The in vivo tolerance of aquatic invertebrates to the presence of low concentrations of dissolved TBT and DBT is not clearly established and only a limited number of studies have addressed the problem. Early studies established that calcification of Crassostrea gigas is inhibited at concentrations $>0.8 \mathrm{ng} \mathrm{Sn} \mathrm{l}^{-1}$ (Chagot et al. 1990), and imposex (reproductive disturbance in neogastropod mollusks) is induced at concentrations of $<1 \mathrm{ng} \mathrm{Sn}^{-1}$ (Gibbs et al. 1987). Valkirs et al. (1987) determined that a concentration of $16 \mathrm{ng} \mathrm{Sn} \mathrm{l}^{-1}$ as TBT was sufficient to interfere with the growth of juvenile mussels, and His \& Robert (1985) found that $17 \mathrm{ng} \mathrm{Sn}$ $\mathrm{l}^{-1}$ as TBT modified the embryogenesis of $C$. gigas. As 
DBT was generally considered much less toxic than TBT (Mason \& Jenkins 1995, Fent 1996), the former was rarely considered in studies conducted at low and very low exposure levels. However, a series of in vitro experiments with marine bivalve hemocytes (Mytilus edulis, Mya arenaria and Mactromeris polynyma) found DBT to be more toxic than TBT (Bouchard et al. 1999). These results were consistent with those of O'Halloran (1996), who reported DBT to significantly suppress mitogenesis of the immune cells of juvenile rainbow trout Oncorhynchus mykiss at doses lower than TBT.

In an exhaustive study on in vivo effects of butyltins on the internal defense of blue mussels (StJean et al. 2002, this issue), we found both TBT and DBT to interfere with hemocyte functions at all doses

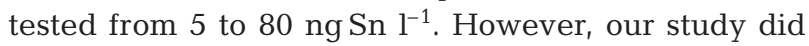
not determine a threshold for modulations to hemocyte function for either TBT or DBT as even the lowest concentration used did provide some positive responses. Using the same experimental set-up and the same end-points previously developed (St-Jean et al. 2002), we exposed groups of mature blue mussels to very low concentrations of TBT and DBT $(1,3$, or $6 \mathrm{ng} \mathrm{Sn} \mathrm{l}^{-1}$ ) with the objective of determining the lowest observable effect level (LOEL) of both TBT and DBT on the very sensitive physiological functions of the immune defense system of this bivalve species.

\section{MATERIALS AND METHODS}

The experimental design for in vivo exposure of mussels to butyltins was previously described (StJean et al. 2002) and only a number of methodological details are given hereafter. All chemicals were either of certified grade for the dyes or HPLC grade for the solvents and were purchased from Sigma Chemical Co. A stock solution of Tris-buffered saline (TBS), pH 8.4, was used as a dilution medium for the dyes. The fixative used was Baker's formol-calcium and consisted of $4 \%(\mathrm{v} / \mathrm{v})$ formaldehyde, $2 \%(\mathrm{w} / \mathrm{v})$ sodium chloride and $1 \%(\mathrm{w} / \mathrm{v})$ calcium acetate (Lowe \& Pipe 1994). The extraction solution used to dissolve the neutral red consisted of $1 \%(\mathrm{v} / \mathrm{v})$ acetic acid plus $50 \%(\mathrm{v} / \mathrm{v})$ ethanol in distilled water (Grundy et al. 1996).

Adult mussels Mytilus edulis, defined as 6 to $8 \mathrm{~cm}$ in shell length, were obtained from a local fisherman at Grande Digue Bay, southern Gulf of St. Lawrence, in September 1998 and immediately transported to the laboratory facilities in Rimouski. They were then cleaned of all epibiont, divided equally among 7 flowthrough aquaria (i.e. 10 mussels aquarium ${ }^{-1}$ ) and allowed to acclimatize for $24 \mathrm{~h}$. Each aquarium (13 l) was supplied with unfiltered seawater pumped from the St. Lawrence Estuary (mean temperature: $11^{\circ} \mathrm{C}$; salinity: $28 \pm 2$ ).

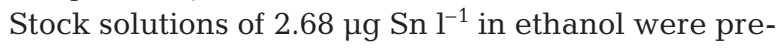
pared for each butyltin, and from these stock solutions, distribution of contaminants to each aquarium was made with peristaltic pumps to obtain final concentrations of 1, 3 and $6 \mathrm{ng} \mathrm{Sn}^{-1}$ for TBT and DBT corresponding to molar concentrations of 8,24 and $48 \mathrm{pM}$. A good mixing of the butyltins and seawater was ensured by delivering the contaminants with a capillary tube inserted into the intake water pipe of each individual aquarium. As the carrier solvent ethanol dissolves in seawater, butyltins stay in solution and do not precipitate.

On each sampling day, $250 \mu \mathrm{l}$ of hemolymph were withdrawn from the posterior adductor muscle sinus of each of the 10 individuals per aquarium with a $20 \mathrm{~g}$ sterile needle attached to a $3 \mathrm{ml}$ sterile syringe containing $250 \mu \mathrm{l}$ of TBS. The resulting $500 \mu \mathrm{l}$ of hemolymph/TBS solution was immediately transferred into 96 well plates, allowing for triplicates of each assay $(3 \times 50 \mu \mathrm{l}$ for phagocytosis and $3 \times 100 \mu \mathrm{l}$ for lysosome retention [LR]) and the remaining $50 \mu \mathrm{l}$ (fixed with Baker's formol) were used for total hemocyte counts (HC) using a Neubauer hematocytometer. Precision of each assay was expressed as the mean coefficient of variation for the triplicates for the 10 mussels and was $11.3 \%$ for phagocytosis, $12.2 \%$ for LR and $4.8 \%$ for HC. Results were expressed as a mean average. Sampling was performed on Days 0 , 1, 4 and 11.

Cell function parameters. LR was evaluated using neutral red dye (Dyrynda et al. 1998). Twenty $\mu \mathrm{l}$ of $2 \%$ neutral red were added to $100 \mu \mathrm{l}$ of hemolymph/TBS suspension in microplate wells for 30 min during which time the hemocytes attached themselves to the bottom and sides of the well creating a monolayer. Plates were then angled draining the supernatant, and the attached hemocytes were gently rinsed with TBS. The neutral red was then extracted by displacing it from the hemocytes with the addition of $100 \mu \mathrm{l}$ of extraction solution for $30 \mathrm{~min}$, after which the plates were read at $490 \mathrm{~nm}$ using a UV Max spectrophotometer (Molecular Devices). Data reported are optical densities and were standardized to $10^{6}$ cells.

Phagocytosis was determined by adding aliquots of $50 \mu \mathrm{l}$ of hemolymph/TBS to sterile $2 \mathrm{ml}$ Eppendorf tubes. Twenty $\mu \mathrm{l}$ of neutral-red stained zymosan type 1 yeast $\left(2.3 \times 10^{8}\right.$ particles $\left.\mathrm{ml}^{-1}\right)$ were added to each tube for 30 min incubation, after which $100 \mu$ of fixative was added for $30 \mathrm{~min}$. To remove neutral red and/or zymosan not absorbed by phagocytes, each tube was washed twice with TBS by centrifugation $(2000 \times g$ for 
5 min), yielding a clear supernatant. The neutral red dye within phagocytes was then dissolved by adding $100 \mu \mathrm{l}$ of extraction solution for $30 \mathrm{~min}$, the supernatant was transferred into microplate wells and the plates were read at $490 \mathrm{~nm}$ using a UV Max spectrophotometer. Data are reported as optical densities and were standardized to $10^{6}$ cells.

Statistical analysis. Statistical analysis used SPSS and Systat softwares (SPSS) for PC. Distributions of variables were examined for normality in probability plots and tested with Levine's test. Homogeneity of variances among groups to be compared were tested by the $F$-test. When required, data were normalized and/or differences in variances were reduced by transforming data to their natural logarithms. Differences among treatment and control groups for each of TBT and DBT were compared by 2-way analysis of variance (ANOVA) with time and dose as independent variables. Where significant effects were detected, 1-way ANOVAS were performed to look at the effect of dose on each sampling day, with TBT or DBT concentration $\left(0,1,3\right.$ and $\left.6 \mathrm{ng} \mathrm{Sn}^{-1}\right)$ as the independent variable followed by an a posteriori test (least significant difference of means).

To determine if the 2 chemicals, TBT or DBT, affected the end-points differently, we pooled doses (omitting the 0 dose) and did an ANCOVA with day as a covariate and chemical as main effect. If this analysis showed significant interactions, ANCOVAs were performed on each dose separately to determine whether all doses or only some doses differed over time. Where interactions were found in dose-specific analyses, they were described. Where no interactions were found, intercept was tested to determine whether chemicals differed in effect over all days.

In addition, to determine whether both chemicals were capable of achieving the same maximal effect (i.e. a threshold) impacts of TBT and DBT on the day of greatest effect were compared in 2 ways. First, chemical (TBT vs DBT) and dose were compared in a 2-way ANOVA. Second, responses to the highest dose ( $6 \mathrm{ng} \mathrm{Sn}^{-1}$ ) were compared by 1-way ANOVA. The first analysis tested whether both chemicals were effective at a similar dose. The second analysis tested whether both chemicals achieved the same maximal effect. Significant differences are reported where $\mathrm{p}<0.05$.

\section{RESULTS}

\section{Lysosome retention (LR)}

The effect of TBT on LR over time differed with dose (Interaction: $F_{9,144}=3.77, \mathrm{p}<0.001$ ). The day-

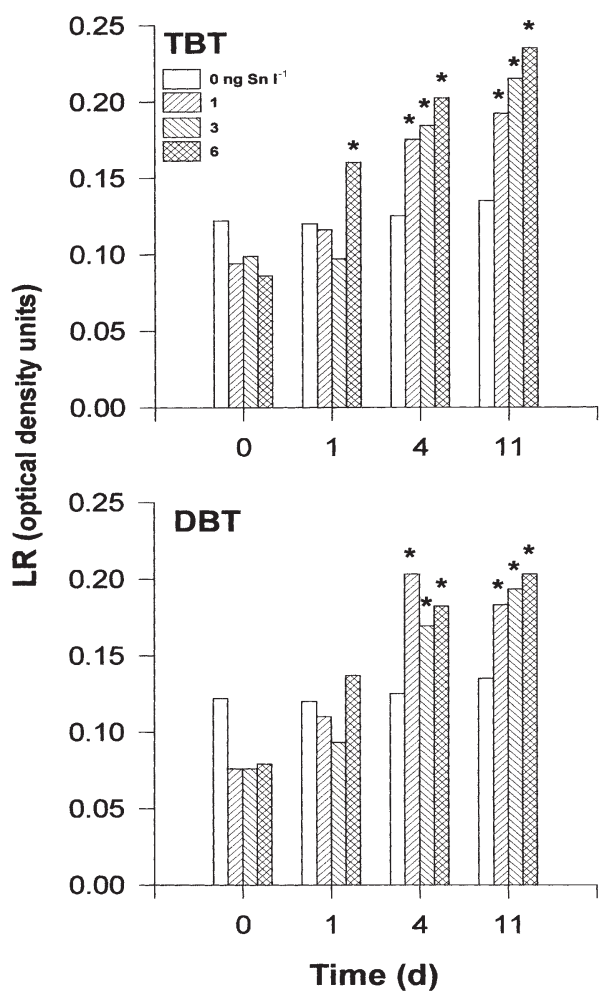

Fig. 1. Mean lysosome retention (LR) measured from 10 adult blue mussels exposed continuously to waterborne tributyltin (TBT) or dibutyltin (DBT) $\left(1,3\right.$ or $\left.6 \mathrm{ng} \mathrm{Sn}^{-1}\right)$ and sampled on Days 0, 1, 4 and 11. Asterisks indicate values statistically different from control

by-day analysis for TBT revealed the following pattern (Fig. 1). The $6 \mathrm{ng} \mathrm{l}^{-1}$ group showed significantly higher LR than the other doses by Day 1, and from Day 4 through Day 11, all doses showed higher LR than the control. For DBT (Fig. 1), all doses showed significantly higher LR than the control by Day 4 and that difference was maintained through to Day 11. Comparison of the impacts of TBT and DBT on LR revealed no differences except that the lowest dose $\left(1 \mathrm{ng} \mathrm{l}^{-1}\right)$ of DBT elevated LR more than TBT, but only on Day 4 (chemical $\times$ time interaction: $F_{3,72}=$ 10.83, p < 0.001). Furthermore, no differences were detected in the maximal elevations of LR achieved by TBT and DBT.

\section{Hemocyte counts (HC)}

In mussels exposed to either TBT or DBT, $\mathrm{HC}$ varied significantly with dose $\left(F_{3,144}=7.54, \mathrm{p}<0.001\right.$ for TBT and $F_{3,144}=5.24, \mathrm{p}<0.001$ for DBT) and over time $\left(F_{3,144}=2.96, \mathrm{p}=0.034\right.$ for TBT and $F_{3,144}=2.24, \mathrm{p}=$ 0.021 for DBT) with no interaction between time and 


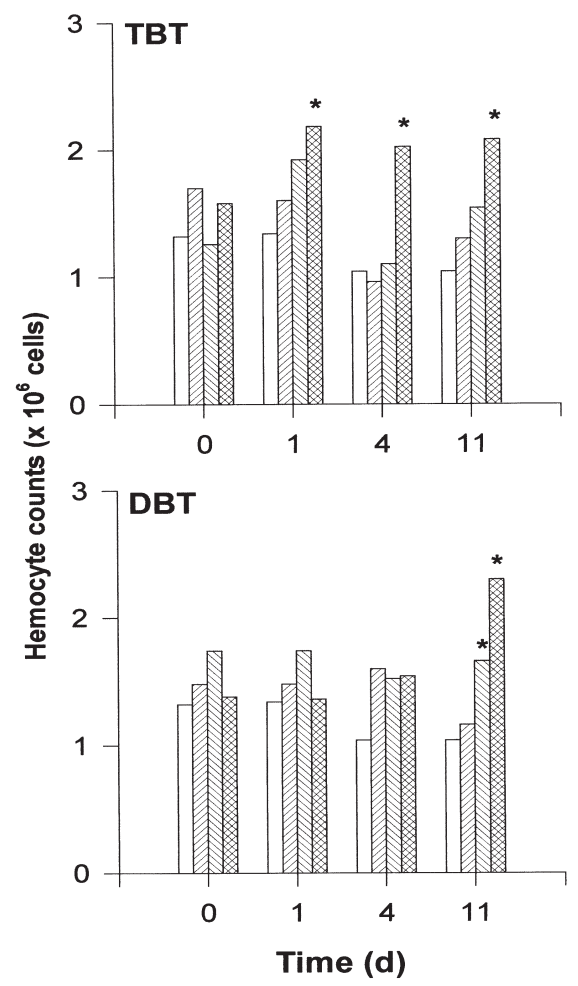

Fig. 2. Mean hemocyte counts (HC) measured from 10 adult blue mussels exposed continuously to waterborne TBT or DBT (1, 3 or $6 \mathrm{ng} \mathrm{Sn}^{-1}$ ) and sampled on Days 0, 1, 4 and 11. Asterisks indicate values statistically different from control

dose. The day-by-day analysis of the trends for TBT (Fig. 2) indicated a significant dose response from Day 1 to the end of the experiment on Day 11, with the $6 \mathrm{ng} \mathrm{l}^{-1}$ group showing significantly higher $\mathrm{HC}$ than the lower doses and control, which did not differ significantly. DBT appeared slower than TBT to affect HC (Fig. 2), showing first significant effects on Day 11, when the 3 and $6 \mathrm{ng} \mathrm{l}^{-1}$ groups showed higher cell counts than the $1 \mathrm{ng} \mathrm{l}^{-1}$ and control groups. ANCOVA revealed that TBT had a significantly greater effect than DBT overall on HC (intercept: $F_{1,236}=4.60, \mathrm{p}=$ $0.033)$. However, the maximal effect, produced by $6 \mathrm{ng}$ $\mathrm{l}^{-1}$ on Day 11, was greater for DBT than TBT $\left(F_{1,18}=\right.$ 96.64, $\mathrm{p}<0.001)$.

\section{Phagocytic activity (PA)}

PA in mussels exposed to DBT varied significantly with dose $\left(F_{3,144}=6.64, \mathrm{p}<0.001\right)$ and over time $\left(F_{3,144}\right.$ $=43.56, \mathrm{p}<0.001$ ) without interaction (Fig. 3). By contrast, no dose effect was detected for TBT (Fig. 3), though PA varied significantly (significant time effect) over the $11 \mathrm{~d}$ of exposure $\left(F_{3,144}=34.74, \mathrm{p}<0.001\right)$.
Mussels exposed to $6 \mathrm{ng} \mathrm{l}^{-1}$ DBT showed increased PA 4 and $11 \mathrm{~d}$ after exposure began. Lower doses of DBT and all doses of TBT did not alter PA significantly from that observed in controls, on any day. The ANCOVA revealed differences in the effect of TBT and DBT in the 2 highest doses tested ( 3 and $6 \mathrm{ng} \mathrm{Sn}^{-1}$ ), with DBT eliciting a greater increase in PA than TBT (chemical $\times$ time interactions: $F_{3,72}=4.93, \mathrm{p}=0.004$ for $3 \mathrm{ng} \mathrm{l}^{-1} ; F_{3,72}$ $=4.32, \mathrm{p}=0.007$ for $6 \mathrm{ng} \mathrm{l}^{-1}$ ). The maximal effect achieved by doses between 1 and $6 \mathrm{ng} \mathrm{l}^{-1} \mathrm{DBT}$, on Day 11, was significantly greater than that achieved by TBT (treatment: $F_{1,54}=28.82, \mathrm{p}<0.001$ ).

\section{DISCUSSION}

Our attempt to determine the lowest observable effect level (LOEL) of both TBT and DBT on the immune system of Mytilus edulis was partially successful, as even the lowest concentration used $\left(1 \mathrm{ng} \mathrm{Sn} \mathrm{l}^{-1}\right)$ had a significant effect on the LR response after $4 \mathrm{~d}$ of exposure. Therefore the unbounded LOEL for modulation of some hemocyte functions in the blue mussel is apparently less than $1 \mathrm{ng} \mathrm{Sn}^{-1}$ and probably lower than LOELs previously observed for TBT for some

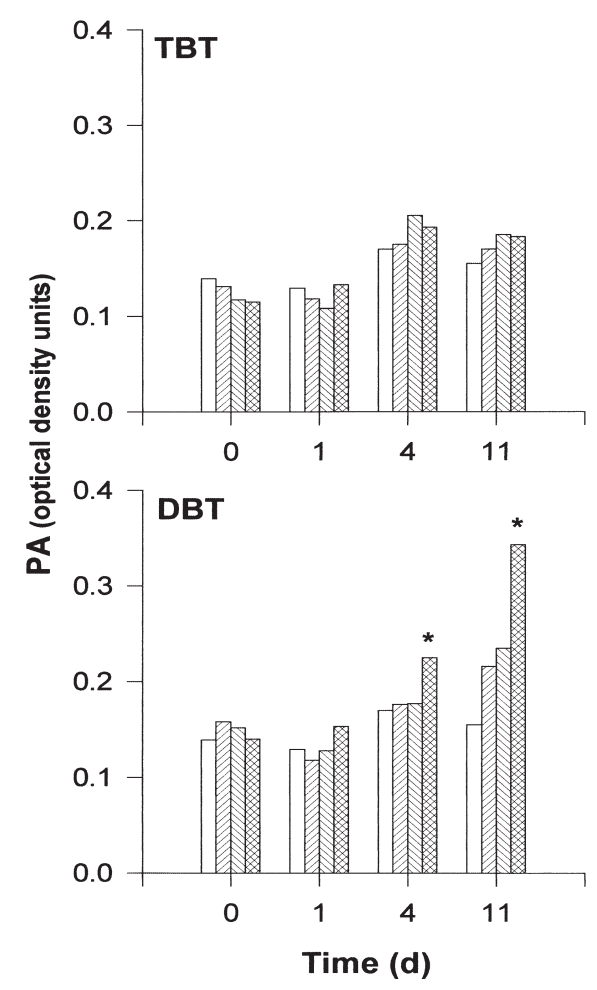

Fig. 3. Mean phagocytic activity (PA) measured from 10 adult blue mussels exposed continuously to waterborne TBT or DBT (1, 3 or $6 \mathrm{ng} \mathrm{Sn} \mathrm{l}^{-1}$ ) and sampled on Days 0, 1, 4 and 11. Asterisks indicate values statistically different from control 
other physiological processes mentioned in the 'Introduction', such as oyster calcification and neogastropod imposex (Gibbs et al. 1987, Chagot et al. 1990). The second important finding of this study is the unexpectedly strong effect of DBT, which induced comparable responses to TBT for all indicators.

The interaction of environmental pollutants with cellular and humoral components of the immune system may suppress or enhance immune responses (Cima et al. 1999). Hemocyte numbers, PA and LR have been shown to increase significantly under stressful conditions or following short-term, low-level contaminant exposures (Anderson 1981, Moore 1988, Renwrantz 1990).

As reported and discussed in our previous paper (St-Jean et al. 2002), PA measured by a spectrophotometric technique was increased significantly at doses of 40 and $80 \mathrm{ngSn} \mathrm{l}^{-1}$ after $6 \mathrm{~d}$. PA increase was again observed in the present experiment but for DBT only at $6 \mathrm{ng} \mathrm{Sn}^{-1}$ after $4 \mathrm{~d}$. PA is a complex process involving many steps at the cytoplasmic membrane level, where TBT and DBT are expected to be very active. At very low concentration, only the stimulating action of DBT was observed. This result supports the idea that the mechanism of cytotoxicity of DBT should be considered different from that of TBT mainly because DBT is a less lypophilic moity than TBT and shows more affinity for plasma membrane-associated sulfide groups (Boyer 1989, Ambrosini et al. 1996).

LR was the most rapid and sensitive indicator of the hemocyte response to the presence of TBT and DBT in the hemolymph of the mussels. These results provide additional support to our previous suggestion that lysosomes are easily overloaded and probably damaged by high concentrations of butyltins (St-Jean et al. 2002). With very low concentrations used in the present experiment, the retention of the dye by hemocytes increased steadily from Day 4 for all concentrations of both toxicants and showed no indication of a decrease after $11 \mathrm{~d}$ of continuous exposure. Lysosomes did not reach their maximum retention capacity and probably preserved their integrity. This finding provides another indication that the immune system of the mussels was stimulated by the presence of low concentrations of TBT and DBT, but apparently not damaged.

Despite the partial ban on use of TBT in marine paints imposed by most industrialized countries in the last 2 decades, levels of organotins in coastal waters reported in the literature are routinely higher than the LOEL reported in this study (Dowson et al. 1992, Fent \& Hunn 1995, Larsen et al. 1997, Michel \& Averty 1999). The energetic costs of this apparent stimulation of immune capability may be high, with possible detrimental implications for long-term exposure (Pipe et al. 1999). It is therefore possible that a constant stress is being applied to the immune systems of mussels and other bivalves in those environments, rendering them more vulnerable to pathogens, infections or other diseases. The present in vivo results obtained under flow-through conditions at very low concentrations represent progress from previous in vitro assays but cannot yet be extrapolated to field conditions where a number of other confounding factors can be present.

The current literature on the physiological impacts (growth reduction, mortality, cytotoxicity, etc.) of butyltins usually ranks their toxicity as TBT $>$ DBT > MBT. However, one of the key problems encountered in ecotoxicology is that certain compounds are species- or even organ- and system-specific, and hence any extrapolation about general toxicity of a given pollutant is to be considered carefully (Fent 1996). Information available on the immunotoxicity of butyltins, especially for aquatic organisms, is not only scarce but also conflicting, presumably reflecting differences among species and organs studied and methods used (Seinen et al. 1981, Snoeij et al. 1988, Wester et al. 1990).

In invertebrate in vitro studies, Bouchard et al. (1999) showed DBT to interfere more than TBT with the PA of 3 bivalve species and, in a study of LR, seastar Leptasterias polaris amoebocytes exposed to DBT absorbed neutral red dye more rapidly and in greater volume than amoebocytes exposed to TBT (I. Taupeau \& É. Pelletier unpubl. data) reflecting a greater impact of DBT on the permeability of the lysosome membrane. The only previous comparative in vivo study of immunomodulative effects of TBT and DBT on blue mussels reported that both butyltins altered immune parameters at doses between 5 and $80 \mathrm{ng} \mathrm{Sn} \mathrm{l}^{-1}$ within $10 \mathrm{~d}$ of exposure (St-Jean et al. 2002). It has been suggested that DBT could be selectively immunotoxic, affecting only the immune system with no apparent effects on other organs/systems (Wester et al. 1990). In light of these reports, there is an urgent need to reassess the toxicity, and particularly the immunotoxicity, of DBT. This compound is less strictly regulated and more widely used (as a stabilizer in PVC and CPVC plastics) than TBT. Studies on the presence of butyltins have reported the presence of DBT in household textiles, diaper covers and sanitary panties in Japan (Yamada et al. 1993), in trace amounts in fruit drinks and wines (Forsyth et al. 1992a,b); in poultry and turkey from the USA (Epsein et al. 1991) and even in canned bivalves (Forsyth \& Cleroux 1991).

In conclusion, this study indicates that both TBT and DBT caused immunomodulations in the blue mussel within $4 \mathrm{~d}$ of exposure at $1 \mathrm{ng} \mathrm{l^{-1 }}$. The unbounded 
LOEL for the immune system of this species is therefore $<1 \mathrm{ng} \mathrm{l}^{-1}$, a concentration often difficult to detect in seawater and already reported for the induction of imposex in neogastropods (Gibbs et al. 1987). Furthermore, our study points out a potential ecosystem health threat for wild and cultured bivalves, associated with immunotoxic butyltins that are routinely found in coastal waters at levels exceeding the LOEL observed for invertebrates.

Acknowledgements. The authors wish to thank Mr. Ghislain Canuel for his excellent technical assistance and suggestions. Also, a special thanks for Mr. Joe Caissie for his supply of mussels. This work was funded through an NSERC doctoral scholarship and through a New Brunswick doctoral scholarship to S.D.S.J., through the Toxic Chemicals Fund of the Canadian Department of Fisheries and Oceans (S.C.C.), as well as through an NSERC operational grant (E.P.).

\section{LITERATURE CITED}

Ambrosini A, Bertoli E, Zolese G (1996) Effect of organotin compounds on membrane lipids: fluorescence spectroscopy studies. Am Fish Soc Symp 8:38-50

Anderson RS (1981) Effects of carcinogenic and non-carcinogenic environmental pollutants on immunological functions in marine invertebrates. In: Dawe CJ, Harshbarger JC, Kondo S, Sagimura T, Takayama S (eds) Phylogenetic approach to cancer. Jpn Sci Soc Press, Tokyo, p 319-331

Bouchard N, Pelletier É, Fournier M (1999) Effects of butyltin compounds on phagocytic activity of haemocytes from three marine bivalves. Environ Toxicol Chem 18: $519-522$

Boyer IJ (1989) Toxicity of dibutyltin, tributyltin and other organotin compounds to humans and to experimental animals. Toxicology 55:253-298

Chagot D, Alzieu C, Sanjuan J, Grizel H (1990) Sublethal and histopathological effects of trace levels of tributyltin fluoride on adult oysters Crassostrea gigas. Aquat Living Resour 3:121-130

Cima F, Martin MG, Matozzo V, DaRos L, Ballarin L (1999) Biomarkers for TBT immunotoxicity studies and the cultivated clam Tapes philippinarum (Adams and Reeve, 1850). Mar Pollut Bull 39:112-115

de Mora SJ (1996) Tributyltin: case study of an environmental contaminant. Cambridge University Press, Cambridge

Dowson PH, Bubb JM, Lester LN (1992) Organotin distribution in sediments and waters of selected east coast estuaries in the UK. Mar Pollut Bull 24:492-498

Dyrynda EA, Pipe RK, Burt GR, Ratcliffe NA (1998) Modulations in the immune defenses of the mussels (Mytilus edulis) from contaminated sites in the UK. Aquat Toxicol 42:169-185

Epsein RL, Phillippo ET, Harr R, Koscinski W, Vasco G (1991) Organotin residue determination in poultry and turkey sample survey in the United States. J Agric Food Chem 39: 917-921

Fent K (1996) Ecotoxicology of organotin compounds. Crit Rev Toxicol 26:1-117

Fent K, Hunn J (1995) Organotins in freshwater harbors and rivers: temporal distribution, annual trends and fate. Environ Toxicol Chem 14:1123-1132
Forsyth DS, Cleroux C (1991) Determination of butyltin, methyltin and tetraalkyltin in marine food products with gas chromatography-atomic absorption spectrometry. Talanta 38(9):951-957

Forsyth DS, Weber D, Barlow L (1992a) The determination of organotin compounds in fruit juices using gas chromatography-atomic absorption spectrometry. Appl Organometal Chem 6:579-585

Forsyth DS, Weber D, Cleroux C (1992b) Determination of butyltin, cyclohexyltin and phenyltin compounds in beers and wines. Food Addit Contam 9:161-169

Gibbs PE, Pascoe PL, Burt GR (1987) Sex change in the female dogwelk, Nucella lapillus, induced by tributyltin from antifouling paints. J Mar Biol Assoc UK 68:715-731

Grundy MM, Moore MN, Howell SM, Ratcliffe NA (1996) Phagocytic reduction and effects on lysosomal membranes by polycyclic aromatic hydrocarbons, in haemocytes of Mytilus edulis. Aquat Toxicol 34:273-290

Hashimoto S, Watanabe M, Noda Y, Hayashi T, Kurita Y, Takasu Y, Otsuki A (1998) Concentration and distribution of butyltin compounds in a heavy tanker route in the Strait of Malacca and in Tokyo Bay. Mar Environ Res 45: 169-177

Higashiyama T, Shiraishi H, Otsuki A, Hashimoto S (1991) Concentrations of organotin compounds in blue mussels from the wharves of Tokyo Bay. Mar Pollut Bull 22: $585-587$

His E, Robert R (1985) Développement des véligères de Crassostrea gigas dans le bassin d'Arcachon études sur les mortalités larvaires. Rev Trav Inst Pech Marit 47(1/2): $63-88$

Kure LK, Depledge MH (1994) Accumulation of organotin in Littorina littorea and Mya arenaria from Danish coastal waters. Environ Pollut 84:149-157

Larsen PF, Huggett RJ, Unger MA (1997) Assessment of organotin in waters of selected Gulf of Maine estuaries. Mar Pollut Bull 34:802-804

Lowe DM, Pipe RK (1994) Contaminant induced lysosomal membrane damage in marine mussel digestive cells: an in vitro study. Aquat Toxicol 30:357-365

Mason AZ, Jenkins KD (1995) Metal detoxification in aquatic organisms. In: Tessier A, Turner DR (eds) Metal speciation and bioavailability in aquatic systems. Wiley \& Sons, New York, p 479-608

Michel P, Averty B (1999) Contamination of French coastal waters by organotins compounds: 1997 update. Mar Pollut Bull 38:268-275

Moore (1988) Cytochemical responses of the lysosomal system and NADPH-ferrihemoprotein reductase in molluscan digestive cells to environmental and experimental exposure to xenobiotics. Mar Ecol Prog Ser 46:81-89

O'Halloran K, Ahokas JT, Wright PFA (1996) Response of fish immune cells to in vitro organotin exposures. Aquat Toxicol 40:141-156

Pipe RK, Coles JA, Carissan FMM, Ramanathan K (1999) Copper induced immunomodulation in the marine mussel, Mytilus edulis. Aquat Toxicol 46:43-54

Renwrantz L (1990) Internal defense system of Mytilus edulis. In: Stefano GB (ed) Studies in neuroscience, neurobiology of Mytilus edulis. Manchester University Press, Manchester, p 256-275

Seinen W, Helder T, Vernij H, Penniks A, Leeuwangh P (1981) Short-term toxicity of tri- $n$-butyltin chloride in rainbow trout (Salmo gairdneri Richardson) yolk sac fry. Sci Total Environ 19:155-166

St-Jean SD, Courtenay SC, Pelletier É (1999) Butyltin concentrations in sediments and blue mussels (Mytilus edulis) of 
the southern Gulf of St. Lawrence, Canada. Environ Technol 20:181-190

St-Jean SD, Pelletier É, Courtenay SC (2002) Hemocyte functions and bacterial clearance affected in vivo by TBT and DBT in the blue mussels Mytilus edulis. Mar Ecol Prog Ser 236:163-178

Snoeij NJ, Penniks AH, Seinen W (1988) Dibutyltin and tributyltin compounds induce thymus atrophy in rats due to a selective action on thymic lymphoblasts. Int J Immunopharmacol 10:891-899

Valkirs AO, Stellard MO, Seligman PF (1987) Butyltin parti-

Editorial responsibility: Otto Kinne (Editor),

Oldendorf/Luhe, Germany tioning in marine waters. Proc Organotin Symp Oceans. 1987 Conf Marine Technology Society, Washington, DC, p 1375-1380

Wester PW, Canton JH, Van Iexsel AAJ, Kranjc EI, Vaessen HAMG (1990) The toxicity of bis(tri-n-butyltin)oxide (TBTO) and di-n-butyltindichloride (DBTC) in the small fish species Oryzias latipes (medeka) and Poecilia reticulata (guppy). Aquat Toxicol 16:53-72

Yamada S, Fujii Y, Mikami E, Kawamura N, Hayakawa J (1993) Small-scale survey of organotin compounds in household commodities. AOAC Int J 76 (2):436-441

Submitted: May 28, 2001; Accepted: December 6, 2001 Proofs received from author(s): May 21, 2002 